\title{
Pengaruh Motivasi dan Kepribadian terhadap Organizational Citizenship Behavior dengan Budaya Organisasi sebagai Variabel Moderasi
}

\author{
Desi Nur Haryati \\ Manajemen, Universitas Sarjanawiyata Tamansiswa, Indonesia \\ Korespondensi penulis: desynurharyati77@gmail.com
}

\begin{abstract}
The phenomenon of development in the Srandakan sub-district as a route to Yogyakarta International Airport (YIA), a new airport in Kulon Progo, Yogyakarta affects public service needs. The staffs of Srandakan sub-district demanded to improve their self-quality which is reflected in organizational citizenship behavior (OCB). The purpose of his study is to find effects of motivation and personality on organizational citizenship behavior with organizational culture was put as a moderation variable. The sample used in this research is all personnel in the Srandakan sub-district office. In this study, the analysis was carried out using descriptive and inferential analysis methods. In order to conduct the inferential analysis of this study, the Partial Least Square (PLS), which is variance-based of structural equation model (SEM), is used as an analytical tool with SmartPLS 3.2.7 software. The result showed that no significant effect of motivation on Organizational Citizenship Behavior (OCB). Otherwise, there are significant effects of personality and organizational culture on organizational citizenship behavior. Finally, organizational culture can not be a moderating effect of motivation and personality on organizational citizenship behavior.
\end{abstract}

Keywords: Motivation; Personality; Organizational culture; Organizational Citizenship Behavior (OCB).

Abstrak. Fenomena pembangunan di wilayah Kecamatan Srandakan sebagai jalur
perjalanan menuju bandara baru Yogyakarta Internatioanal Airport (YIA) di Kabupaten
Kulon Progo, Yogyakarta mempengaruhi kebutuhan pelayanan publik. Pegawai Keca-
matan Srandakan dituntut untuk meningkatkan kualitas diri yang tercermin pada Orga-
nizational Citizenship Behavior (OCB). Penelitian ini bertujuan untuk menganalisis
peng-aruh motivasi dan kepribadian terhadap OCB dengan menempatkan budaya
organisasi sebagai variabel moderasi. Sampel yang digunakan dalam penelitian ini ada-
lah semua pegawai di Kantor Kecamatan Srandakan, Kabupaten Kulon Progo, Yogya-
karta, Indonesia. Dalam penelitian ini, analisis dilakukan dengan menggunakan metode
analisis diskriptif dan analisis inferensial. Untuk melakukan analisis inferensial, alat
analisis yang digunakan adalah Partial Least Square (PLS), yaitu SEM (Structural
Equation Model) yang berbasis varian dan menggunakan alat bantu software SmartPLS
3.2.7. Hasil penelitian ini menunjukkan tidak ada pengaruh signifikan variabel motivasi
terhadap OCB. Di sisi lain, penelitian ini menemukan adanya pengaruh signifikan 
variabel kepribadian dan budaya organisasi terhadap OCB. Selanjutnya, variabel budaya organisasi tidak dapat memoderasi pengaruh motivasi dan kepribadian terhadap OCB.

Kata kunci: Motivasi; Kepribadian; Budaya organisasi; Organizational Citizenship Behavior (OCB).

Article Info:

Received: March 7, $2019 \quad$ Accepted: November 7, $2019 \quad$ Available Online: November 8, 2019 DOI: http://dx.doi.org/10.30588/jmp.v9i1.433

\section{LATAR BELAKANG}

Saat ini, pemerintah melakukan pembangunan bandar udara (bandara) baru yang diberi nama Yogyakarta Internatioanal Airport (YIA). Bandara Yogyakarta yang baru tersebut dibangun di wilayah Kabupaten Kulon Progo, Yogyakarta dan memberikan dampak bagi lingkungan sekitar. Selain itu, pembangunan bandara berdampak pada jalur perlintasan transportasi antardaerah. Salah satunya adalah wilayah Kecamatan Srandakan, Kabupaten Kulon Progo yang menjadi jalur utama penghubung antara Kota Yogyakarta dengan bandara YIA (Turseno, 2018):

Pembangunan bandara baru New Yogyakarta International Airport (NYIA)

di Kabupaten Kulonprogo, meskipun baru memasuki tahap awal sudah mulai berdampak ke beberapa wilayah. Tak terkecuali Desa Trimurti, Kecamatan Srandakan mulai menyambut dengan rencana mendirikan tempat peristirahatan (rest area).

Peningkatan pembangunan dan infrastruktur di wilayah Kecamatan Srandakan akan mempengaruhi aktifitas perekonomian masyarakat sekitar. Bertambahnya aktivitas masyarakat tersebut akan meningkatkan kebutuhan layanan administrasi. Dengan peningkatan kebutuhan tersebut, Kecamatan Srandakan sebagai lembaga pemerintah yang berwenang dituntut untuk meningkatkan kualitas layanan.

Perilaku yang senantiasa ditunjukkan oleh pegawai tidak hanya perilaku yang sesuai peranannya saja (in-role), tetapi mereka juga diharapkan dapat lebih menampilkan perilaku extra-role atau Organizational Citizenship Behavior (OCB) (Organ, 1988). OCB sangat dibutuhkan di dalam setiap organisasi, seperti kantor kecamatan. Sebagai sebuah kantor pemerintahan yang bersifat non-profit, kantor kecamatan memiliki pekerjaan utama memberikan layanan kepada masyarakat sebagai user dengan sopan, ramah, baik, dan penuh sukarela. OCB adalah perilaku extra-role sebagai tindakan yang tidak ada di dalam job description pegawai, tetapi dilakukan dengan senang hati, sukarela dalam melakukan pekerjaan, tolong menolong sesama pegawai tanpa diminta dan tanpa pamrih.

Pegawai kecamatan sebagai bagian dari pegawai pemerintah memiliki kompensasi yang minim perubahan. Minimnya perubahan ini dikarenakan pegawai kecamatan mengikuti atura Kompensasi yang ada tersebut berpengaruh terhadap OCB pegawai kecamatan, seperti penelitian. Prasetya dan Yuniawan (2016) menyatakan bahwa kompensasi finansial memiliki pengaruh positif terhadap OCB. Kompensasi yang diperoleh minimal akan berpengaruh terhadap OCB yang rendah oleh pegawai kecamatan tanpa adanya motivasi dan kepribadian yang baik dalam diri mereka sendiri, tanpa 
ditambah adanya pengaruh eksternal, seperti budaya organisasi. Pada dasarnya, setiap manusia memiliki motivasi untuk bekerja. Motivasi adalah dorongan di dalam diri manusia yang memberikan energi dan mengaktifkan serta menggerakkan arah perilaku untuk mencapai tujuan tertentu (Barnes dalam Rivai, 2015). Pegawai merasa dihargai dan bermanfaat bagi masyarakat umum yang mereka layani. Perasaan seperti itulah yang dapat memberikan pengaruh pada perilaku OCB. Danendra dan Mujiati (2016) menyatakan bahwa motivasi berpengaruh positif dan signifikan terhadap OCB.

Kesukarelaan dan kemampuan seseorang untuk membantu orang lain dipengaruhi oleh kepribadian (personality) dan suasana hati (mood) (Organ, 1988). Kepribadian merupakan faktor yang melekat dalam diri dan lebih sulit diubah, sehingga memiliki pengaruh yang relatif stabil dan bertahan pada OCB (Alwisol, 2010). Kepribadian yang baik akan membentuk perilaku yang baik. Dengan demikian, di dalam diri pegawai Kecamatan Srandakan diharapkan terbentuk OCB sebagai salah satu upaya peningkatan kualitas sumber daya manusia (SDM). Peningkatan pembangunan dan infastruktur idealnya diimbangi dengan perbaikan kualitas SDM. SDM dapat meningkatkan kemampuan bekerja melalui faktor kepribadian sebagai pendukungnya.

Selain faktor dari dalam diri pegawai, seperti motivasi dan kepribadian, ada pula faktor dari luar yang dapat mempengaruhi OCB, yaitu budaya organisasi. Budaya organisasi adalah sebuah sistem yang digunakan untuk melaksanakan pekerjaan dalam suatu organisasi demi tercapainya tujuan organisasi tersebut secara maksimal (Robbins, 2017). Untuk itu, budaya organisasi secara tidak langsung dapat mempengaruhi terbentuknya perilaku OCB di dalam organisasi kecamatan.

Fenomena pembangunan di wilayah Kecamatan Srandakan sebagai jalur transportasi menuju bandara baru di Kabupaten Kulon Progo mempengaruhi kebutuhan layanan publik. Pegawai Kantor Kecamatan Srandakan seharusnya mampu meningkatkan kualitas diri yang tercermin melalui organizational citizenship behavior. Penelitian ini bertujuan untuk menganalisis pengaruh motivasi dan kepribadian pegawai Kantor Kecamatan Srandakan terhadap organizational citizenship behavior dengan budaya organisasi sebagai variabel moderasi.

\section{KAJIAN TEORITIS}

Organizational citizenship behavior (OCB) merupakan kontribusi individu yang melebihi perannya di tempat kerja (Robbins, 2017). OCB melibatkan perilaku menolong orang lain, menjadi volunteer untuk tugas-tugas ekstra, dan patuh terhadap aturan-aturan dan prosedur-prosedur di tempat kerja. Peningkatan OCB dipengaruhi oleh dua faktor utama, yaitu faktor internal (kepuasan kerja, komitmen, kepribadian, moral karyawan, motivasi, dan sebagainya) dan faktor eksternal (gaya kepemimpinan, kepercayaan pada pemimpin, budaya organisasi, dan sebagainya). Namun, penelitian ini membahas kepribadian dan motivasi sebagai variabel independen dan menempatkan budaya organisasi sebagai variabel moderasi. Model yang digunakan dalam penelitian ini dapat dilihat pada Gambar 1 berikut. Variabel-variabel dan hubungan antarvariabel yang dikaji dalam penelitian ini diuraikan sebagai berikut: 


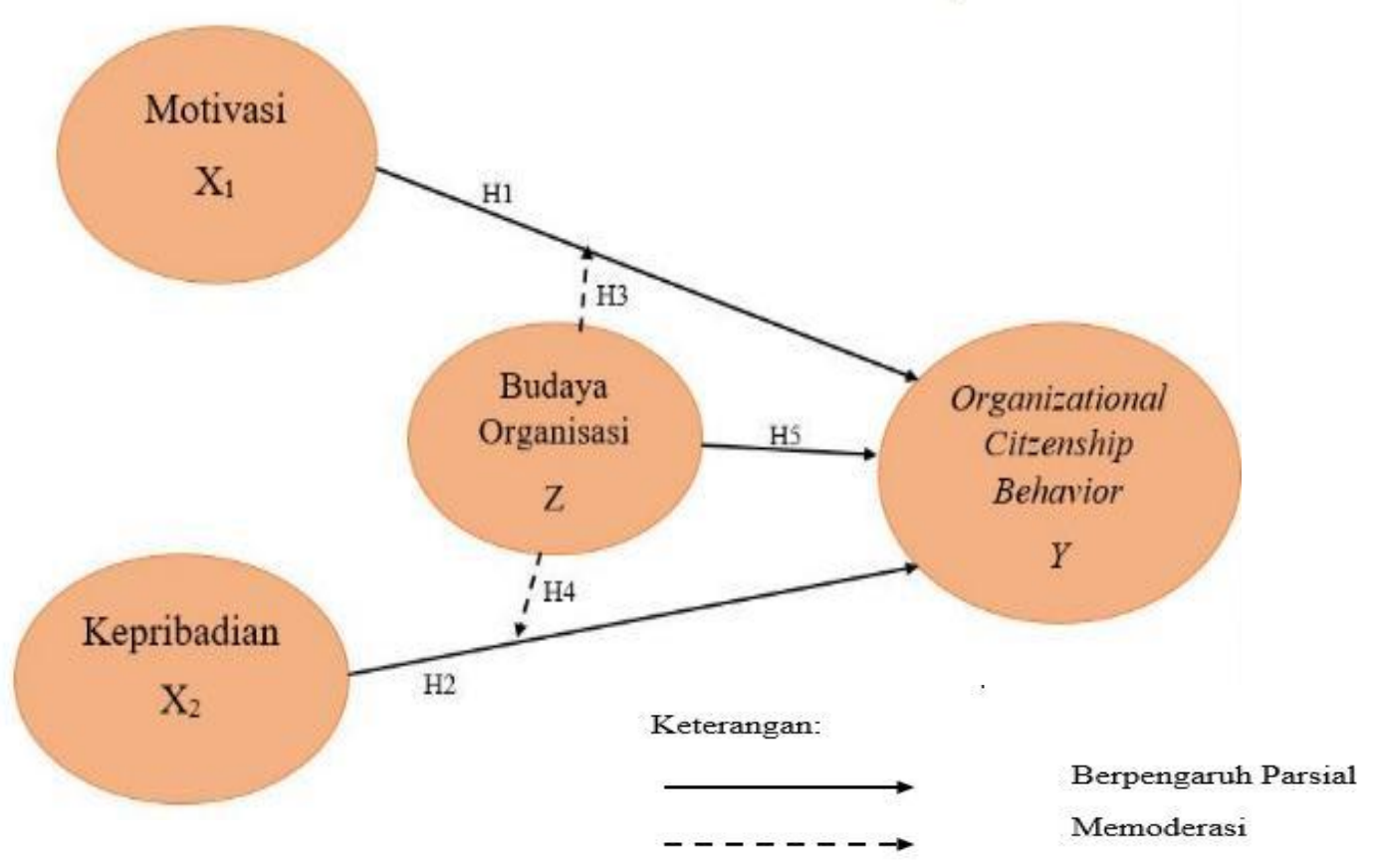

Gambar 1. Model Penelitian

\section{Pengaruh Motivasi terhadap Organizational Citizenship Behavior}

Jennifer dan Jones (2012) mengemukakan bahwa karyawan yang memiliki perilaku yang baik, mau berusaha dan bekerja keras, serta tidak mudah menyerah merupakan ciri-ciri dari perilaku OCB, sehingga motivasi kerja yang tinggi sangat mempengaruhi timbulnya perilaku OCB di dalam organisasi. Penelitian yang dilakukan oleh Danendra dan Mujiati (2016) menyatakan bahwa motivasi berpengaruh positif dan signifikan terhadap OCB.

\section{H1: Ada pengaruh positif dan signifikan motivasi terhadap organizational citizen- ship behavior.}

\section{Pengaruh Kepribadian terhadap Organizational Citizenship Behavior}

Kepribadian dan suasana hati mempunyai pengaruh terhadap timbulnya perilaku OCB secara individual maupun kelompok. Jennifer dan Jones (2012) mengemukakan bahwa kemauan seseorang untuk membantu orang lain dipengaruhi oleh mood. Kepribadian merupakan karakteristik yang secara relatif dapat berubah-ubah (Alwisol, 2010). Sebuah suasana hati yang positif akan meningkatkan peluang seseorang untuk membantu orang lain. Meskipun suasana hati dipengaruhi oleh sebagian kepribadian, ia juga dipengaruhi oleh situasi. Hubungan antara kepribadian dan OCB direfleksikan ketika seorang pegawai memiliki kepribadian yang baik dan mampu mengelola suasana hati, maka ia akan cenderung mampu berperilaku extra-role atau OCB (Robbins, 2017) . Dengan demikian, kepribadian menjadi faktor internal terbentuknya perilaku OCB. 
Sambung (2014) menunjukkan adanya pengaruh positif dan signifikan kepribadian terhadap OCB.

\section{$\mathrm{H}_{2}$ : Ada pengaruh positif dan signifikan kepribadian terhadap organizational citizenship behavior.}

\section{Pengaruh Motivasi terhadap Organizational Citizenship Behavior yang dimoderasi oleh Budaya Organisasi}

Organ (dalam Titisari, 2014) menjelaskan bahwa budaya dan iklim organi-sasi merupakan kondisi awal yang memicu terjadinya OCB. Budaya dan iklim organisasi dapat menjadi penyebab kuat berkembangnya OCB dalam organisasi. Ketika iklim organisasi positif, maka anggota organisasi akan melakukan pekerjaan melebihi kewajiban seharusnya dan akan selalu mendukung tujuan organisasi. Hal tersebut terjadi apabila atasan memperlakukan semua anggota organisasi secara adil. OCB muncul sebagai perwujudan motivasi intrinsik, misalnya kepribadian, mood, dan minat tertentu.

\section{$\mathrm{H}_{3}$ : Ada pengaruh positif dan signifikan motivasi terhadap orgnizational citizen- ship behavior setelah dimoderasi oleh budaya organisasi.}

\section{Pengaruh Kepribadian terhadap Organizational Citzenship Behavior yang dimoderasi Budaya Organisasi}

Organ (dalam Luthans, 2012) mengkategorikan faktor yang mempengaruhi OCB terdiri atas perbedaan individu, sikap kerja, dan variabel kontekstual yaitu: (a) Perbedaan individu termasuk sifat stabil yang dimiliki individu meliputi kepribadian (misalnya kesadaran dan keramahan), kemampuan, pengalaman, pelatihan, pengetahuan, motivasi, kebutuhan, dan nilai individu; (b) Sikap kerja adalah emosi dan kognisi yang didasarkan pada persepsi individu terhadap lingkungan kerja meliputi komitmen organisasi, persepsi kepemimpinan, dukungan organisasi, person organization fit, kepuasan kerja, psychological contract, persepsi keadilan, dan keadilan organisasi; dan (c) Faktor-faktor kontekstual yaitu pengaruh eksternal yang berasal dari pekerjaan, tim kerja, organisasi, atau lingkungan.

\section{$\mathrm{H}_{4}$ : Ada pengaruh positif dan signifikan kepribadian terhadap organizational citizenship behavior setelah dimoderasi oleh budaya organisasi.}

\section{Pengaruh Budaya Organisasi terhadap Organizational Citzenship Behavior}

OCB lebih berkaitan dengan manifestasi seseorang (karyawan) sebagai makhluk sosial. OCB merupakan bentuk kegiatan sukarela anggota organisasi yang mendukung fungsi organisasi, sehingga perilaku ini lebih bersifat altruistik (menolong) yang diekspresikan dalam bentuk tindakan-tindakan yang menunjukkan sikap tidak mementingkan diri sendiri dan perhatian pada kesejahteraan orang lain (Muhdar, 2015). Budaya organisasi (corporate culture) merupakan suatu sistem kepercayaan-kepercayaan dan nilainilai yang berkembang dalam organisasi dan mengarahkan perilaku anggotanya. Dalam bisnis, sistem-sistem ini sering dianggap sebagai corporate culture. Tidak ada dua pribadi yang sama, tidak ada budaya organisasi yang identik. Para ahli dan konsultan mempercayai bahwa perbedaan budaya memiliki pengaruh yang besar pada kinerja 
organisasional dan kualitas kehidupan kerja yang dialami oleh anggota organisasi (Yohanas, 2013). Dengan demikian, budaya organisasi berpengaruh positif secara langsung terhadap OCB.

\section{$\mathrm{H}_{5}$ : Ada pengaruh positif dan signifikan budaya organisasi terhadap organiza- tional citizenship behavior.}

\section{METODE PENELITIAN}

Populasi yang digunakan dalam penelitian ini adalah semua pegawai di Kantor Kecamatan Srandakan, Kabupaten Kulon Progo, Yogyakarta. Menurut Arikunto (2013), apabila subyek kurang dari seratus, lebih baik populasi diambil semua, sehingga penelitiannya merupakan penelitian populasi (sensus). Namun, jika jumlah subyek cukup besar, maka sampel dapat diambil antara 10-15\% atau 15-25\% atau lebih. Pendapat tersebut selaras dengan pendapat Roscoes (Sugiyono, 2014) yang menyebutkan bahwa ukuran sampel yang layak dalam sebuah penelitian berkisar antara 30 sampai dengan 500 unit.

Populasi dalam penelitian ini berjumlah 49 orang terdiri atas bagian anggota kecamatan, Unit Pengelola Kegiatan (UPK), Pendamping Layanan Keluarga Berencana (PLKB), Pendamping Desa, Pendamping Penerima Keluarga Harapan (PKH), Pendamping Izin Usaha Mikro Kecil (IUMK), dan Pendamping Tenaga Kesejahteraan Sosial Kecamatan (TKSK). Berdasarkan pendapat Arikunto (2013), sampel pada penelitian ini adalah populasi karena jumlahnya kurang dari seratus unit, sehingga penelitian ini disebut penelitian populasi atau menggunakan metode sensus.

Jenis data dalam penelitian ini adalah data primer yang dikumpulkan dengan teknik pengumpulan data menggunakan kuesioner. Instrumen penelitian dalam bentuk kuesioner atau angket menggunakan teknik skala Likert dengan skor 1-5. Metode angket merupakan pernyataan tertulis yang digunakan untuk memperoleh informasi dari responden dalam arti laporan tentang pribadi atau hal-hal yang ia ketahui (Arikunto, 2013). Angket atau kuesioner merupakan teknik pengumpulan data yang dilakukan dengan cara memberikan sejumlah pertanyaan atau pernyataan tertulis kepada responden untuk dijawab (Sugiyono, 2014). Pernyataan yang diajukan bersifat tertutup, sehingga responden langsung memberikan tanda pada salah satu pilihan jawaban yang dianggap paling benar. Ketepatan instrumen dalam penelitian ini diukur validitas dan reliabilitasnya.

Dalam penelitian ini, analisis data menggunakan metode diskriptif dan inferensial. Analisis inferensial dalam penelitian ini menggunakan Partial Least Square (PLS), yaitu Structural Equation Model (SEM) yang berbasis varian dengan bantuan software SmartPLS 3.2.7. PLS adalah salah satu teknik Structural Equation Modeling (SEM) yang mampu menganalisis variabel laten, variabel indikator, dan kesalahan pengukuran secara langsung (Wiyono, 2011). PLS merupakan metode analisis yang powerfull karena dapat diterapkan pada semua skala data, tidak banyak membutuhkan asumsi, dan ukuran sampel yang tidak harus besar (Wardoyo, 2013). Selanjutnya, model path analysis digunakan untuk menganalisis pola hubungan antarvariabel dengan tujuan mengetahui pengaruh langsung maupun tidak langsung seperangkat variabel bebas (eksogen) terhadap variabel terikat (endogen). Model path analysis menunjukkan pola hubungan sebab-akibat (Alma, 2013). 


\section{HASIL PENELITIAN DAN PEMBAHASAN}

Dari 49 kuesioner yang disampaikan kepada responden, 41 di antaranya melengkapi jawaban sesuai pertanyaan yang diberikan, sedangkan 7 responden tidak mengembalikan atau tidak melengkapi jawabannya. Jadi, jumlah responden yang digunakan dalam penelitian ini adalah 41 orang atau response rate mencapai 83,67\%. Gambaran umum responden dalam penelitian ini dilihat dari karakteristik yang meliputi usia, jenis kelamin, tingkat pendidikan, status perkawinan, dan masa kerja responden. Gambaran umum mengenai profil responden dalam penelitian ini dapat dilihat dalam Tabel 1.

Tabel 1. Karakteristik Responden

\begin{tabular}{|c|c|c|c|}
\hline Karakteristik & Pilihan Jawaban & $\begin{array}{c}\text { Jumlah } \\
\text { Responden }\end{array}$ & Persentase \\
\hline \multirow{6}{*}{ Usia } & Tidak Menjawab & 1 & $2,44 \%$ \\
\hline & $20-35$ & 16 & $39,02 \%$ \\
\hline & $36-45$ & 11 & $26,83 \%$ \\
\hline & $46-55$ & 9 & $21,95 \%$ \\
\hline & $>56$ & 4 & $9,76 \%$ \\
\hline & Total & 41 & $100,00 \%$ \\
\hline \multirow{4}{*}{ Jenis kelamin } & Tidak Menjawab & 0 & $0 \%$ \\
\hline & Pria & 21 & $51,22 \%$ \\
\hline & Wanita & 20 & $48,78 \%$ \\
\hline & Total & 41 & $100,00 \%$ \\
\hline \multirow{7}{*}{ Tingkat pendidikan } & Tidak Menjawab & 0 & $0 \%$ \\
\hline & SMP & 0 & $0 \%$ \\
\hline & SMA & 8 & $19,51 \%$ \\
\hline & Diploma & 7 & $17,07 \%$ \\
\hline & Sarjana & 24 & $58,54 \%$ \\
\hline & Magister & 2 & $4,88 \%$ \\
\hline & Total & 41 & $100,00 \%$ \\
\hline \multirow{5}{*}{ Status perkawinan } & Tidak Menjawab & 0 & $0 \%$ \\
\hline & Kawin & 28 & $68,29 \%$ \\
\hline & Belum Kawin & 11 & $26,83 \%$ \\
\hline & Janda/Duda & 2 & $4,88 \%$ \\
\hline & Total & 41 & $100,00 \%$ \\
\hline \multirow{7}{*}{ Masa kerja } & Tidak Menjawab & 4 & $9,76 \%$ \\
\hline & $0-5$ tahun & 17 & $41,46 \%$ \\
\hline & 6-10 tahun & 4 & $9,76 \%$ \\
\hline & 11-15 tahun & 0 & $0 \%$ \\
\hline & 16-20 tahun & 7 & $17,07 \%$ \\
\hline & $>21$ tahun & 9 & $21,95 \%$ \\
\hline & Total & 41 & $100,00 \%$ \\
\hline
\end{tabular}

Sumber: Data primer diolah (2019).

Dari Tabel 1, mayoritas responden dalam penelitian ini berada dalam usia produktif, yaitu antara 20 sampai dengan 45 tahun, sehingga mereka masih akan merasakan dampak perkembangan pendirian bandara baru YIA. Jenis kelamin responden relatif berimbang, sehingga tidak memperlihatkan adanya ketimpangan gender pada kepegawaian di Kecamatan Srandakan. Jumlah responden paling besar berpendidikan sarjana. Dengan pendidikan tinggi tersebut, wawasan dan kesempatan pegawai untuk berkembang masih terbuka luas. Mayoritas responden berstatus telah menikah atau berkeluarga, sehingga responden seharusnya memiliki motivasi lebih tinggi dalam bekerja. Selanjut- 
nya, paling banyak responden bermasa kerja antara 0-5 tahun yang menunjukkan bahwa mereka masih memiliki masa kerja yang panjang ke depannya untuk mengembangkan diri.

Seluruh butir pada pertanyaan untuk setiap variabel dalam penelitian memiliki status valid, karena nilai r-hitung (Corrected Item-Total Correlation) < r-tabel sebesar 0,308 . Hasil koefisien reliabilitas instrumen motivasi sebesar 0,834 , instrumen kepribadian sebesar 0,866, instrumen budaya organisasi sebesar 0,924 dan instrumen organizational citizenship behavior sebesar 0,827. Semua nilai koefisien tersebut memiliki nilai Cronbach's Alpha lebih besar dari 0,600 yang berarti keempat instrumen dinyatakan andal atau memenuhi persyaratan reliabilitas.

Analisis model SEM dengan program SmartPLS terdiri atas beberapa tahapan. Model teoritis yang telah dibangun pada tahap pertama digambarkan dalam sebuah diagram model SEM yang akan mempermudah melihat hubungan-hubungan kausal yang ingin diuji. Dalam diagram tersebut (Gambar 2), hubungan antarkonstrak dinyatakan dengan anak panah. Anak panah menunjukkan sebuah hubungan kausal langsung antara satu konstrak dengan konstrak lainnya.

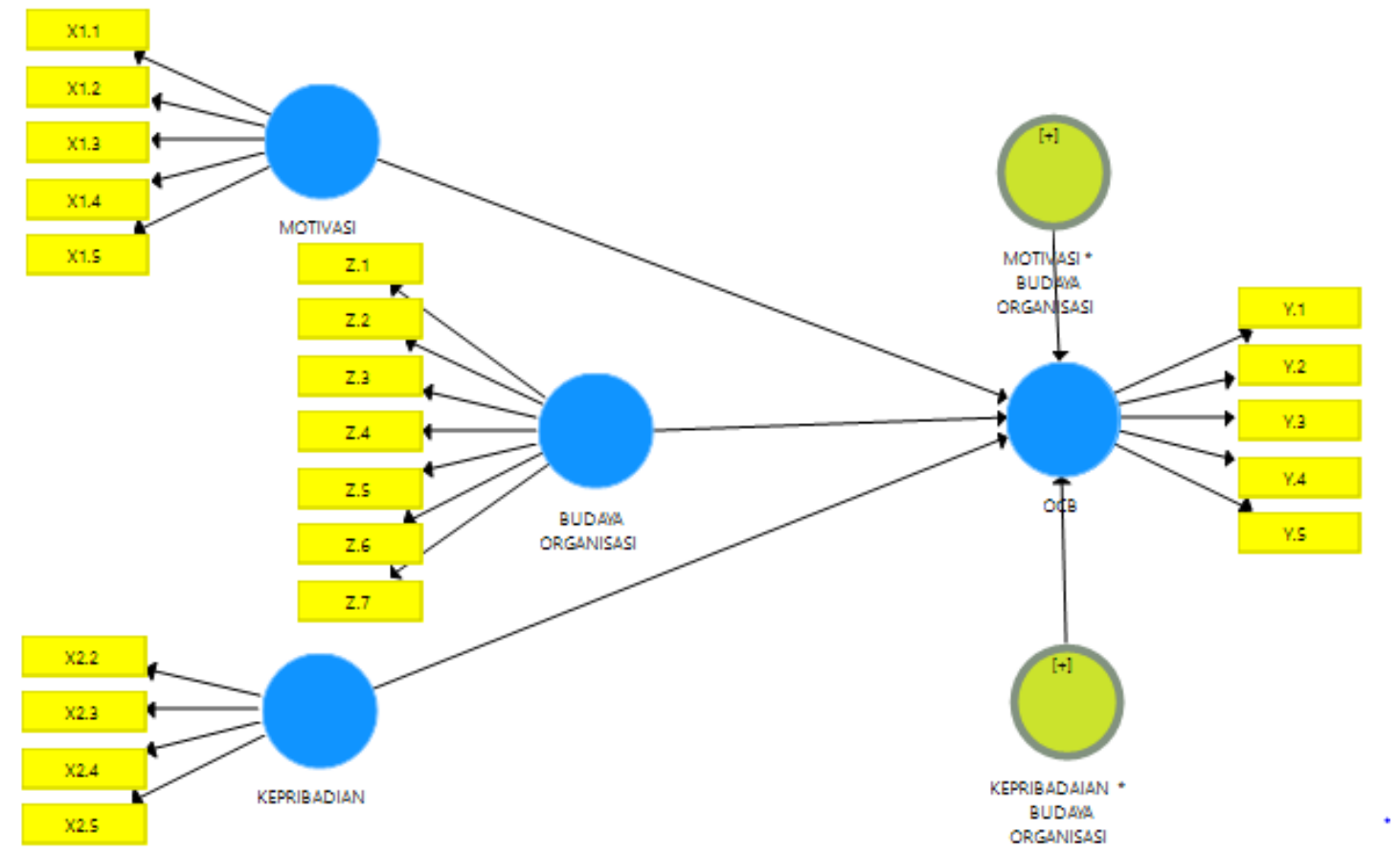

Gambar 2. Skema Model Partial Least Square

Setelah pemeriksaan outer model (model pengukuran) terpenuhi, maka selanjutnya pemeriksaan dilakukan terhadap inner model (model struktural). Pemeriksaan ini meliputi signifikasi hubungan jalur dan nilai R Square $\left(\mathrm{R}^{2}\right)$ untuk melihat hasil evaluasi model struktural, khususnya signifikasi variabel moderasi. Nilai $\mathrm{R}^{2}$ bertujuan untuk mengetahui seberapa besar variabel independen mempengaruhi variabel dependennya, 
sedangkan untuk melihat kontribusi variabel moderasi terhadap model dapat dilihat dari efeknya.

Nilai R-square sebesar 0,827 menunjukkan variabilitas konstrak OCB dipengaruhi oleh konstrak motivasi, kepribadian, budaya organisasi, dan interaksinya sebesar $82 \%$, sedangkan $18 \%$ sisanya dipengaruhi oleh variabel lain yang tidak terdapat dalam model penelitian ini. Uji hipotesis pada penelitian ini dilakukan dengan melihat nilai tstatistic atau pun nilai p-values. Hipotesis penelitian dapat diterima apabila nilai pvalues $<0,05$. Berikut ini adalah hasil uji hipotesis yang diperoleh melalui olah data pada inner model.

Tabel 3. Uji Hipotesis Berdasarkan p-values

\begin{tabular}{|c|l|c|c|l|}
\hline Hipotesis & \multicolumn{1}{|c|}{ Pengaruh Variabel } & p-values & Keterangan & \multicolumn{1}{|c|}{ Hasil } \\
\hline H1 & Motivasi terhadap OCB & 0,291 & p-values $>0,05$ & Hipotesis ditolak \\
\hline H2 & Kepribadian terhadap OCB & 0,000 & $\mathrm{p}$-values $<0,05$ & Hipotesis diterima \\
\hline H3 & $\begin{array}{l}\text { Motivasi dimoderasi Budaya } \\
\text { Organisasi terhadap OCB }\end{array}$ & 0,813 & p-values $>0,05$ & Hipotesis ditolak \\
\hline H4 & $\begin{array}{l}\text { Kepribadian dimoderasi Budaya } \\
\text { Organisasi terhadap OCB }\end{array}$ & 0,153 & p-values $>0,05$ & Hipotesis ditolak \\
\hline H5 & $\begin{array}{l}\text { Budaya Organisasi terhadap } \\
\text { OCB }\end{array}$ & 0,000 & p-values $<0,05$ & Hipotesis diterima \\
\hline
\end{tabular}

Sumber: Data primer diolah (2019).

Berdasarkan hasil olah data pada Tabel 3, dari lima hipotesis yang diajukan dalam penelitian ini, dua hipotesis dapat diterima, karena masing-masing pengaruh memiliki nilai p-values $<0,05$, sehingga kedua variabel independen memiliki pengaruh yang signifikan terhadap OCB. Tiga hipotesis lain dalam penelitian ini ditolak, karena memiliki p-values $>0,05$, karena pengaruh variabel independen terhadap dependennya tidak signifikan dan tidak terjadi hubungan moderasi.

Uji hipotesis 1 (H1) dalam penelitian ini menunjukkan bahwa konstrak motivasi tidak berpengaruh terhadap OCB. Hasil analisis jalur diperoleh bahwa t-statistik < ttabel 2,0 sebesar 1,058 dengan nilai signifikasi 0,291 >0,05. Hasil tersebut menunjukkan bahwa $\mathrm{H} 1$ ditolak atau $\mathrm{H} 0$ diterima. Hasil penelitian ini tidak sejalan dengan penelitian yang dilakukan oleh Danendra dan Mujiati (2016) yang mengatakan bahwa motivasi berpengaruh positif dan signifikan terhadap OCB. Artinya, pegawai yang memiliki perilaku baik, mau berusaha, dan bekerja keras, serta tidak mudah menyerah tidak menjadi ciri-ciri perilaku OCB, sehingga motivasi kerja yang tinggi tidak mempengaruhi timbulnya perilaku OCB di dalam organisasi.

Indikator-indikator variabel motivasi dalam penelitian ini mendapatkan hasil jawaban kurang baik. Pada kebutuhan fisik terdapat dua pernyataan yang memiliki jawaban kurang baik, yaitu pernyataan pada penerimaan tunjangan yang sesuai dengan pekerjaan yang dibebankan dan penerimaan fasilitas yang layak dengan persentase $27 \%$ dan $24 \%$. Pada indikator kebutuhan keamanan semua pernyataan memiliki jawaban kurang baik tidak setuju dan netral, yaitu pada pernyataan mendapatkan fasilitas kesehatan, mendapatkan keamanan pada kerugian fisik, dan mendapatkan keamanan pada kerugian emosional dengan persentase $7 \%, 22 \%$, dan 5\%. Pada indikator penghargaan diri terdapat dua pernyataan yang memiliki jawaban tidak setuju, yaitu pada pernyataan atasan memberikan pujian atas kerja yang dilakukan dan pengabdian yang diakui oleh 
atasan dengan persentase $7 \%$ dan $2 \%$. Dari uraian tersebut di atas, faktor yang menyebabkan motivasi tidak berpengaruh terhadap OCB pada pegawai di Kantor Kecamatan Srandakan disebabkan adanya beberapa dimensi variabel motivasi yang tidak terpenuhi.

Hipotesis 2 (H2) menunjukkan bahwa konstrak kepribadian berpengaruh terhadap OCB. Dengan nilai t-statistik > t-tabel 2,0 sebesar 3,573. Hasil penelitian ini sejalan dengan hasil penelitian Sambung (2014) yang menyatakan bahwa variabel kepribadian berpengaruh terhadap OCB di Universitas Palangka Raya. Demikian pula dengan penelitian Hendri et al. (2017) di Fakultas Keguruan dan Pendidikan Universitas Mulawarman. Menurut Robbins (2017), lima indikator kepribadian, yaitu ekstroversi, kemampuan bersepakat, kemampuan mendengarkan suara hati, stabilitas emosi, serta sensitivitas dan keingintahuan. Kelima indikator tersebut memiliki nilai yang positif bagi pegawai Kantor Kecamatan Srandakan.

Hasil uji hipotesis 3 (H3) menunjukkan bahwa tidak ada pengaruh motivasi terhadap OCB yang dimoderasi budaya organisasi. Nilai signifikasi efek interaksi atau moderasi ditunjukkan oleh t-statistik $0,236<$ t-tabel 2,0. Dengan demikian, budaya organisasi tidak memoderasi pengaruh motivasi terhadap OCB. Dengan kata lain, naik turunnya budaya organisasi tidak mempengaruhi secara signifikan pengaruh motivasi terhadap OCB. Meskipun budaya organisasi merupakan faktor ekternal terbentuknya OCB, tetapi sebagai variabel moderasi, budaya organisasi tidak memiliki pengaruh. Dalam penelitian ini, tidak terjadi hubungan moderasi antara budaya organisasi terhadap hubungan motivasi dan OCB pegawai di Kantor Kecamatan Srandakan. Dengan demikian, pengujian ini menolak hipotesis ke-3 yang menyatakan adanya pengaruh motivasi terhadap OCB yang dimoderasi budaya organisasi.

Hasil uji hipotesis $4(\mathrm{H} 4)$ menunjukkan bahwa tidak ada pengaruh kepribadian terhadap OCB yang dimodersi budaya organisasi. Nilai signifikasi efek interaksi atau moderasi ditunjukkan oleh t-staistik 1,431<t-tabel 2,0. Hasil tersebut mengindikasikan bahwa budya organisasi bukan sebagai pemoderasi kepribadian terhadap OCB. Dengan kata lain, naik turunya budaya organisasi tidak mempengaruhi secara signifikan hubungan kepribadian terhadap OCB. Budaya organisasi dikatakan sebagai faktor eksternal terbentuknya OCB, tetapi sebagai varibel moderasi, budaya organisasi tidak memiliki pengaruh. Dalam penelitian ini, tidak terjadi hubungan moderasi antara budaya organisasi terhadap hubungan antara kepribadian dan OCB pegawai di Kantor Kecamatan Srandakan. Jadi, pengujian ini menolak hipotesis ke-4 yang menyatakan ada pengaruh kepribadian terhadap OCB yang dimoderasi budaya organisasi.

Hasil uji hipotesis 5 (H5) menunjukkan bahwa konstrak budaya organisasi berpengaruh terhadap OCB. Dengan nilai t-staistik > t tabel 2,0 sebesar 3,803, H5 diterima dan H0 ditolak. Hasil penelitian ini sejalan dengan penelitian Nugraha dan Adnyani (2018) yang mengatakan bahwa ada pengaruh budaya organisasi secara parsial terhadap OCB pada Kantor Sekretariat Daerah Kota Denpasar. Dalam kehidupan berorganisasi, OCB bersifat sosial. OCB membantu mengubah suasana organisasi yang formal menjadi lebih santai dan penuh dengan kerjasama. OCB adalah tindakan ekstra yang tidak formal atau tertulis dalam peratuan organisasi. Hal ini diharapkan dapat mengurangi ketegangan antarpegawai, sehingga dapat meningkatkan produktifitas kerja, sehingga tercapai efisiensi dan keefektifan kerja.

Dari hasil penelitian ini, variabel motivasi tidak berpengaruh signifikan terhadap pegawai di Kantor Kecamatan Srandakan. Motivasi kerja melibatkan dua fak- 
tor, yaitu individu dan organisasi. Faktor individu meliputi kebutuhan, tujuan, dan kemampuan. Faktor organisasi meliputi kompensasi, keamanan, pujian, job desk dan penghargaan dari organisasi lainnya. Hal ini dikarenakan pegawai di Kantor Kecamatan Srandakan merasa tidak puas dengan organisasi di dalamnya. Mereka tidak mendapatkan faktor penting yang mempengaruhi motivasi kerja, yaitu kebutuhan fisik dan sosial. Dari indikator-indikator kuesioner yang diperoleh menunjukkan bahwa banyak pegawai kecamatan yang tidak mendapatkan fasilitas layak, jaminan kesehatan, dan perlindungan. Dengan demikian, pegawai Kantor Kecamatan Srandakan merasa tidak puas dengan apa yang mereka dapatkan, sehingga motivasi kerja mereka rendah. Motivasi kerja yang rendah tidak mampu mendukung terciptanya OCB.

Menurut Wirawan (2014), faktor-faktor yang dapat mempengaruhi OCB, yaitu kepribadian, budaya organisasi, iklim organisasi, kepuasan kerja, komitmen organisasi, kepemimpinan transformasional, servant leadership, tanggung jawab sosial pegawai, umur pegawai, keterlibatan kerja, kolektivisme, serta keadilan organisasi. Dalam penelitian ini, kepribadian berpengaruh terhadap OCB. Pegawai Kantor Kecamatan Srandakan memiliki kepribadian yang baik, antara lain mudah berinteraksi dengan orang lain, senang melakukan kerja sama antarrekan kerja, dan mereka mudah menerima peraturan baru meskipun motivasi kerjanya rendah.

Kepribadian dapat terlihat dari sebuah tindakan. OCB lebih berkaitan dengan manifestasi seorang pegawai sebagai makhluk sosial. Perilaku ekstra merupakan tindakan yang dilakukan oleh pegawai yang tidak ada dalam peraturan formal. Perilaku pegawai terbentuk dengan adanya budaya organisasi. Dalam penelitian ini, budaya organisasi secara parsial berpengaruh terhadap OCB. Budaya organisasi yang mendukung terbentuknya OCB di Kantor Kecamatan Srandakan, antara lain tuntutan displin waktu, tutuntan bekerja sama antarrekan kerja, dan penyelesaian permasalahan yang timbul dalam organisasi secara kolektif atau kekeluargaan. Meskipun secara parsial, budaya organisasi berpengaruh terhadap OCB. Namun, budaya organisasi tidak dapat menjadi pemoderasi pada variabel motivasi maupun variabel kepribadian di dalam penelitian ini. Artinya, naik turunnya budaya organisasi tidak mempengaruhi secara signifikan hubungan motivasi terhadap OCB maupun pengaruh kepribadian terhadap OCB. Meskipun budaya organisasi dikatakan sebagai faktor ekternal terbentuknya OCB, budaya organisasi tidak memiliki pengaruh sebagai varibel moderasi.

\section{KESIMPULAN DAN SARAN}

Berdasarkan hasil penelitian ini, tidak ditemukan adanya pengaruh signifikan motivasi terhadap OCB. Namun, penelitian ini menemukan adanya pengaruh signifikan kepribadian dan budaya organisasi terhadap OCB. Selain itu, hasil ini juga menemukan bahwa budaya organisasi tidak mampu memoderasi pengaruh motivasi dan kepribadian terhadap OCB. Penelitian ini masih memiliki beberapa keterbatasan. Waktu yang singkat dalam pelaksanaan penelitian menyebabkan kurangnya variasi dan rincian tindakan maupun data penelitian yang diperoleh dengan berkembangnya proyek pembangunan bandara baru YIA. Penelitian ini dilakukan masih secara umum, sehingga masih kurang melakukan spesifikasi permasalahan yang dihadapi. 
Berdasarkan hasil penelitian ini, maka terdapat beberapa saran yang dapat diberikan oleh peneliti. Kantor Kecamatan Srandakan memiliki pegawai dengan kepribadian dan OCB yang baik, pimpinan kantor perlu menjaga konsistensinya agar tujuan organisasi tercapai. Untuk mempertahankan hal tersebut, budaya organisasi yang lebih baik harus bisa diciptakan. Budaya organisasi di Kantor Kecamatan Srandakan dianggap masih memiliki nilai yang cukup rendah. Budaya organisasi tersebut mencakup pemberian pemahaman yang mudah dan sosialisasi yang tepat agar pegawai dapat menerima peraturan baru di Kantor Kecamatan Srandakan. Tingkat kedisplinan dan konsistensi pegawai terhadap pekerjaannya perlu ditingkatkan agar lebih baik melalui peran aktif atasan dan kemampuan memberikan arahan yang runtut.

Pimpinan Kantor Kecamatan Srandakan disarankan untuk meningkatkan motivasi kerja para pegawainya, karena tingkat motivasi pegawai memiliki nilai terendah dibandingkan variabel lainnya. Dari butir pernyataan yang ditampilkan, ketersediaan tunjangan yang sesuai dengan beban kerja pegawai dan fasilitas yang layak, terutama fasilitas kesehatan merupakan sebagian harapan mereka. Suasana kerja yang harmonis dapat diciptakan melalui hubungan antarrekan kerja. Pimpinan perlu memberikan pujian kepada bawahan yang berprestasi agar mereka merasa dihargai. Hal tersebut merupakan salah satu cara meningkatkan motivasi kerja di lingkungan Kantor Kecamatan Srandakan yang tidak banyak merasakan perubahan. Selain itu, pegawai dapat diberikan kesempatan lebih luas untuk berpartisipasi dalam menentukan tujuan organisasi.

Untuk penelitian selanjutnya, penggunaan faktor OCB yang lebih banyak sangat disarankan, seperti faktor internal (kepuasan kerja, komitmen, kepribadian, moral karyawan, dan motivasi) dan faktor eksternal (gaya kepemimpinan, kepercayaan pada pemimpin, dan budaya organisasi), sehingga penelitian mendatang dapat melihat faktorfaktor mana saja yang dapat mempengaruhi OCB. Selain itu, penelitian berikutnya dapat menggunakan obyek penelitian dengan jenis lingkungan kerja yang berbeda. Lingkungan kerja yang dimaksud adalah organisasi swasta yang memiliki pola kerja dan tata kelola berbeda dengan pegawai pemerintahan (pegawai negeri), sehingga dapat ditemukan perbandingan data atau kebijakan yang lebih baik bagi lingkungan yang diteliti.

\section{DAFTAR REFERENSI}

Alma, B. (2013). Manajemen Pemasaran dan Pemasaran Jasa. Bandung: Alfabeta. Alwisol (2010). Psikologi Kepribadian. Malang: UMM Press.

Arikunto, S. (2013). Prosedur Penelitian: Suatu Pendekatan Praktik. Jakarta: Rineka Cipta.

Danendra, A. \& Mujiati (2016). Pengaruh Motivasi, Kompensasi dan Komitmen Organisasional terhadap Organizational Citizenship Behavior (OCB). E-Journal Manajemen Unud, 5(1), 6229-6259.

Hendri, W. N. (2017). Pengaruh Kepribadian dan Komitmen Organisasi terhadap Organizational Citizenship Behavior (OCB) pada Fakultas Keguruan dan Ilmu Pendidikan Universitas Mulawarman. eJournal Administrative Reform, 5(1), 6982.

Jennifer, G. \& Jones (2012). Understanding and Managing Organizational Behavior. New Jersey: Pearson Education. 
Luthans, F. (2012). Perilaku Organisasi. Edisi ke-10. Yogyakarta: Andi Offset.

Muhdar, T. (2015). Studi Empirik Pengaruh Kecerdasan Spiritual terhadap Organizational Citizenship Behavior dan Kinerja: Sebuah Kajian Literatur. Jurnal AlBuhuts, 10(1), 35-58.

Nugraha, I. \& Adnyani (2018). Pengaruh Budaya Organisasi, Komitmen Organisasi, dan Kompetensi terhadap Organizational Citizenship Behaviour pada Setda Kota Denpasar. E-Jurnal Manajemen, 7(1), 1-28.

Organ, D. W. (1988). Organizational Citizenship Behavior: The Soldier Syndrome. Lexington: Lexinton Books.

Prasetya, S. \& Yuniawan (2016). Analisis Pengaruh Kompensasi Finansial terhadap Organizational Citizenship Behavior (OCB) dengan Disiplin Kerja dan Motivasi Berprestasi sebagai Variabel (Studi pada Badan Narkotika Nasional Provinsi Jawa Tengah). Diponegoro Journal of Management, 5(1), 1-10.

Rivai, V. (2015). Manajemen Sumber Daya Manusia untuk Perusahaan: Dari teori ke Praktik. Edisi Ketiga. Jakarta: Rajawali Press.

Robbins, S. P. (2017). Perilaku Organisasi. Edisi ke-16. Jakarta: Salemba Empat.

Sambung, R. (2014). Pengaruh Kepribadian terhadap Organizational Citizenship Behavior (OCB) dengan Komitmen Organisasional sebagai Intervening. Jurnal Manajemen dan Akuntansi, 3(1), 1-16.

Sugiyono (2014). Metode Penelitian Bisnis. Bandung: Alfabeta.

Titisari, P. (2014). Peranan Organizational Citizenship Behavior (OCB) dalam Meningkatkan Kinerja Karyawan. Jakarta: Mitra Wacana Media.

Turseno, A. (2018). Songsong Bandara Baru, Dirikan Rest Area. Retrieved from Harian Merapi: https://www.harianmerapi.com/news/2018/02/12/7544/songsong-bandara-baru-dirikan-rest-area.

Wardoyo, H. S. (2013). Sructural Equation Modeling untuk Penelitian Manajemen Menggunakan AMOS 18. Bekasi: PT Intermedia Personalia Utama.

Wirawan (2014). Teori Kepemimpinan: Ilmu Perilaku. Bandung: Alfabeta.

Wiyono, G. (2011). Merancang Penelitian Bisnis dengan Alat Analisis SPSS 17.0 \& SmartPLS 2.0. Yogyakarta: UPP STIM YKPN.

Yohanas, O. (2013). Pengaruh Budaya Organisasi, Kemampuan Kerja, dan Komitmen Organisasi terhadap Organizational Citizenship Behavior (OCB) Pegawai Bappeda Kota Pekanbaru. Jurnal Aplikasi Manajemen, 11(1), 65-76. 